\title{
In vitro anti-inflammatory effects of naturally-occurring compounds from two Lauraceae plants
}

\author{
ERICSSON D. COY-BARRERA ${ }^{1,2}$ and LUIS E. CUCA-SUÁREZ ${ }^{1}$ \\ ${ }^{1}$ Laboratorio de Investigación en Productos Naturales Vegetales, Departamento de Química, Facultad de Ciencias, \\ Universidad Nacional de Colombia, Cra 30 No. 45-03, AA 14490, Bogotá D.C., Colombia \\ ${ }^{2}$ Facultad de Ciencias Básicas, Universidad Militar Nueva Granada, Campus Universitario Rio Grande, \\ km 3, Vía Cajicá-Zipaquirá, Cundinamarca, Colombia \\ Manuscript received on February 18, 2010; accepted for publication on May 19, 2011
}

\begin{abstract}
The in vitro anti-inflammatory effects of seven known lignans and one dihydrochalcone isolated from the leaves of two Lauraceae species (Pleurothyrium cinereum and Ocotea macrophylla), were evaluated through the inhibition of COX-1, COX-2, 5-LOX and the aggregation of rabbit platelets induced by PAF, AA and ADP. (+)-de- $4^{\prime \prime}-O$-methylmagnolin 4 was found to be a potent COX-2/5-LOX dual inhibitor and PAF-antagonist (COX-2 IC $502.27 \mu \mathrm{M}$; 5-LOX IC 50 $5.05 \mu \mathrm{M}$; PAF $\left.\mathrm{IC}_{50} 2.51 \mu \mathrm{M}\right)$. However, all compounds exhibited an activity at different levels, indicating good anti-inflammatory properties to be considered in further structural optimization studies.
\end{abstract}

Key words: COX, furofuran lignans, 5-LOX, Ocotea macrophylla, platelet aggregation, Pleurothyrium cinereum.

\section{INTRODUCTION}

Prostaglandin $\mathrm{H}_{2}$ synthase (also named cyclooxygenase, COX), which has three isoforms, COX-1, COX-2 and COX-3 (Simmons et al. 2004), and lipoxygenase (LOX) catalyze the rate-limiting step in the formation of prostaglandins (PGs) and leukotrienes (LTs), respectively. The delineation of their distinct functions in physiological and pathological processes has promoted plenty of studies that are focused on the search for potential anti-inflammatory agents. In this way, COX-2 inhibitors were developed as a safer alternative to traditional nonsteroidal anti-inflammatory drugs (NSAIDs) because there was less risk of gastrointestinal ulceration (Charlier and Michaux 2003).

Platelets, being the smallest cellular component in the blood, change shape from disc-shaped into spiny spheres, in the presence of stimuli such as arachidonic acid (AA). Activated platelets bind to fibrinogen, aggregate and release adenosine diphosphate (ADP) and

Correspondence to: Luis Enrique Cuca Suárez

E-mail: lecucas@unal.edu.co serotonin, among others, contained in their intracellular granules (Rao 1993). Thromboxane $\mathrm{A}_{2}\left(\mathrm{TxA}_{2}\right)$, an AA metabolite, ADP and platelet activating factor (PAF) intensify the extent of platelet aggregation as an autocatalytic process rather than promote an equilibrium response (Armstrong 1996). Under pathophysiological conditions, platelet activation may result in peripheral, cardiovascular or cerebrovascular thrombosis with severe consequences. The relationship between platelet aggregation and acute inflammation had been previously discussed (Prescott et al. 2002), as well as the possible risk of suffering cardiovascular problems (myocardial infarction and thromboembolic events) by using COX-2-specific inhibitors, since the healthy balance between COX-2-mediated prostacyclin and COX1-dependent thromboxane is disturbed (Konstam et al. 2001). Therefore, the search for COX inhibitory compounds with antiplatelet effects, which possess a different mechanism from that of NSAIDS, appeared to be a relevant way to provide protection against harmful cardiovascular events in treating inflammatory problems (Bombardier et al. 2000). 
Several Lauraceae plants have shown anti-inflammatory (Lin et al. 2007, da Silva Filho et al. 2004) and anti-platelet (Ballabeni et al. 2007) properties, as well as furofuran and aryltetralin lignans isolated from other families (Kim et al. 2009, Kim and Yun-Choi 2007, Chen et al. 1996). Furthermore, relevant results were obtained in pharmacological studies for the furofuran lignan yangambin, isolated from the leaves of Ocotea duckei (Lauraceae) (Morais et al. 1999), which exhibited excellent cardiovascular properties (Tibiriçá 2001), and was found to differentiate putative PAF receptor subtypes in the gastrointestinal tract of rats (Jesus-Morais et al. 2000). Thus, as part of our research on the biological activity of Lauraceae compounds, this paper reports the in vitro evaluation of the anti-inflammatory and anti-platelet effects of three 1-aryltetralin lignans $\left[(+)\right.$-otobaphenol 1, 4-hydroxy-3-methoxy-3', $4^{\prime}$-methylenedioxy- $\Delta^{7,8,7^{\prime}, 8^{\prime}}-6.7^{\prime}, 8.8^{\prime}$-lignan $2,(8 R)$-3,4-dimethoxy- $3^{\prime}, 4^{\prime}$ - methylenedioxy- $-\Delta^{7^{\prime}, 8^{\prime}}-6.7^{\prime}, 8.8^{\prime}$ - lignan 3$]$, two furofuran lignans $((+)$-de-4" $-O$-methylmagnolin 4 , (+)-demethylpiperitol 5), and a dihydrochalcone (dihydroflavokawin B 6) previously isolated from Pleurothyrium cinereum van der Werff (Coy and Cuca 2008a, b). These properties were assessed through inhibition of COX-1, COX-2, 5-LOX and aggregation of rabbit platelets induced by PAF, AA and ADP, respectively. In addition, two diastereomeric dibenzylbutane lignans (meso-3,4,5,3', $3^{\prime}, 5^{\prime}$-hexamethoxy- $8.8^{\prime}$-lignan 7 and threo-3,4,5,3', $4^{\prime}, 5^{\prime}$-hexamethoxy-8.8'-lignan 8) were isolated from the leaves of Ocotea macrophylla Kunth, which were identified on the basis of spectroscopic analyses $\left({ }^{1} \mathrm{H},{ }^{13} \mathrm{C}\right.$ NMR, 2D NMR, HRMS $)$ (Fig. 1).

\section{MATERIALS AND METHODS}

\section{General Experimental Procedures}

Melting points were determined on a Fisher-Johns melting point apparatus without correction. Ultraviolet (UV) spectra and colorimetric measurements were performed on a Cary 50 Scan (Varian instruments) spectrophotometer. ${ }^{1} \mathrm{H}$ and ${ }^{13} \mathrm{C}$ NMR spectra were recorded on a Bruker Avance 400 spectrometer, using deuterated chloroform $\left(\mathrm{CDCl}_{3}\right)$ as solvent, and tetramethylsilane (TMS) as internal shift reference. High resolution mass spectra
(HRMS) were determined on a micromass quadrupoletime of flight (qToF) (Waters Inc.) [with an electrospray ionization (ESI) source and in the positive ion mode] mass spectrometer. Platelet aggregation was measured on a Chrono-Log (Chrono-Log Corporation) optical aggregometer.

Plant MATERIAL, Extraction AND ISOLATION

Whole plants of $P$. cinereum van der Werff and $O$. macrophylla Kunth were collected in November 2005 in the Awá indigenous reservation in Alto Albí, Tumaco county, department of Nariño, Colombia, and in June 2006 by the side of Nocaima-Vergara road in Nocaima county, department of Cundinamarca, Colombia, respectively. Voucher specimens (numbers COL518334 for P. cinereum and COL517191 for O. macrophylla, which were identified by the botanist Adolfo Jara Muñoz) were deposited at Herbario Nacional Colombiano, Universidad Nacional de Colombia. Detailed extraction and isolation processes for compounds 1-8 have been previously reported (Coy and Cuca, 2008a, b, Coy et al. 2010).

\section{CELls and Reagents}

COX-(ovine) inhibitor screening and 5-LOX-(potato) inhibitor screening kits were purchased from Cayman Chemical Company, Ann Arbor, MI, USA (Catalogs No. 560101 and No. 760700, respectively). AA, PAF, ADP and ginkgolide B were acquired from Sigma-Aldrich. Platelet-rich plasma (PRP) was obtained from blood collected from the central ear artery of female White New Zealand rabbits with a body weight between 3 and $4 \mathrm{~kg}$.

COX-1, COX-2, AND 5-LOX INHIBITION AssAYS

The ability of the test compounds listed in Table I to inhibit ovine COX-1, COX-2, and potato 5-LOX were determined using enzyme immunoassay (EIA) kits, according to the reported methods (Rao et al. 2003, Chowdhury et al. 2008).

Platelet Aggregation Induced by PAF, AA AND ADP

Anti-platelet activity was carried out according to the reported method (Koch 2005), which was approved by 
<smiles>[R][Z]1Cc2cc(OC)c([R9])cc2C(c2ccc3c(c2)OCO3)C1[R]</smiles>

$1 \mathrm{R}^{1}=\beta-\mathrm{CH}_{3} ; \mathrm{R}^{2}=\alpha-\mathrm{CH}_{3} ; \mathrm{R}^{3}=\mathrm{H}$

$2 \mathrm{R}^{1}=\beta-\mathrm{CH}_{3} ; \mathrm{R}^{2}=\mathrm{CH}_{3} ; \mathrm{R}^{3}=\mathrm{H} ; \Delta^{7^{\prime}, 8^{\prime}}$

$3 \mathrm{R}^{1}=\mathrm{CH}_{3} ; \mathrm{R}^{2}=\mathrm{CH}_{3} ; \mathrm{R}^{3}=\mathrm{H} ; \Delta^{7,8 ; 7^{\prime}, 8^{\prime}}$<smiles>COc1cc(O)c(C(=O)CCc2ccccc2)c(OC)c1</smiles>

6<smiles>[R]c1ccc([C@@H]2OC[C@@H]3[C@@H](c4cc([R])c([R4])c([R])c4)OC[C@@H]23)cc1[R]</smiles>

$4 \mathrm{R}^{1}=\mathrm{R}^{2}=\mathrm{R}^{3}=\mathrm{R}^{5}=\mathrm{OCH}_{3} ; \mathrm{R}^{4}=\mathrm{OH}$

$5 \mathrm{R}^{1}, \mathrm{R}^{2}=\mathrm{OCH}_{2} \mathrm{O} ; \mathrm{R}^{3}=\mathrm{R}^{4}=\mathrm{OH} ; \mathrm{R}^{5}=\mathrm{H}$<smiles>[Z]C(C)[C@@H](C)[C@@]([R7])(C)Cc1cc(OC)c(OC)c(OC)c1</smiles>

7 8,8' meso; $\mathrm{R}^{1}=\mathrm{H} \alpha$

$88,8^{\prime}$ threo; $\mathrm{R}^{1}=\mathrm{H} \beta$

Fig. 1 - Structures of compounds 1-8.

TABLE I

COX-1, COX-2 and 5-LOX enzyme inhibition results of compounds $1-8$.

\begin{tabular}{c|c|c|c}
\hline \multirow{2}{*}{ Compound } & \multicolumn{3}{|c}{$\mathrm{IC}_{50}(\mu \mathrm{M})^{\mathrm{a}}$} \\
\cline { 2 - 4 } & COX-1 & COX-2 & 5 -LOX \\
\hline $\mathbf{1}$ & 479 & 49.6 & 8.39 \\
$\mathbf{2}$ & 368 & 65.2 & 9.45 \\
$\mathbf{3}$ & 388 & 80.1 & 116 \\
$\mathbf{4}$ & 35.6 & 2.27 & 5.05 \\
$\mathbf{5}$ & 24.6 & 22.2 & 4.22 \\
$\mathbf{6}$ & 1.22 & 457 & 127 \\
$\mathbf{7}$ & 322 & 16.3 & 46.4 \\
$\mathbf{8}$ & 432 & 15.6 & 78.2 \\
celecoxib & 8.32 & 0.0512 & 11.3 \\
aspirin & 0.411 & 2.53 & - \\
caffeic acid & - & - & 3.73 \\
\hline
\end{tabular}

${ }^{a}$ Values are means of two experiments, standard deviation from the mean is $<10 \%$ of the mean value.

the ethics committee at Universidad Nacional de Colombia. Briefly, convenient PRP was stirred at $800 \mathrm{rpm}$ and maintained at $37^{\circ} \mathrm{C}$. Samples of PRP were preincubated for $5 \mathrm{~min}$ at $37^{\circ} \mathrm{C}$ with test compounds (selected concentrations according to the previous work of Koch 2005) in dimethyl sulfoxide (DMSO). Aggregation was induced by the addition of $10 \mu \mathrm{L}$ diluted PAF, AA or ADP, according to the test. The final concentration was $7.20 \mathrm{nM}$ for PAF, $100 \mu \mathrm{M}$ for AA, and $4.00 \mu \mathrm{M}$ for ADP on PRP. In order to eliminate the effect of the solvent on the aggregation, the final concentration of DMSO was fixed at $0.5 \%$, which did not affect the aggregation measurement. The inhibition of platelet aggregation versus a solvent control was calculated as percentage.

\section{STATISTICS}

Half-maximal inhibition concentrations $\left(\mathrm{IC}_{50}, \mu \mathrm{M}\right)$ were determined by a non-linear regression analysis using GraphPad prism 5.00 (GraphPad software, San Diego, CA, USA). 
TABLE II

Inhibitory effects of compounds 1-8 on the aggregation of rabbit platelets induced by PAF, AA and ADP.

\begin{tabular}{c|c|c|c}
\hline \multirow{2}{*}{ Compound } & \multicolumn{3}{|c}{$\mathrm{IC}_{50}(\mu \mathrm{M})^{\mathrm{a}}$} \\
\cline { 2 - 4 } & PAF $(7.20 \mathrm{nM})$ & $\mathrm{AA}(100 \mu \mathrm{M})$ & $\mathrm{ADP}(4.00 \mu \mathrm{M})$ \\
\hline $\mathbf{1}$ & $846 \pm 67$ & $645 \pm 33$ & $>999$ \\
$\mathbf{2}$ & $140 \pm 13$ & $156 \pm 21$ & $>999$ \\
$\mathbf{3}$ & $24.8 \pm 2.3$ & $28.6 \pm 2.5$ & $77.6 \pm 4.3$ \\
$\mathbf{4}$ & $2.51 \pm 0.16$ & $73.6 \pm 3.1$ & $10.3 \pm 1.8$ \\
$\mathbf{5}$ & $3.84 \pm 0.45$ & $74.7 \pm 2.8$ & $15.6 \pm 1.4$ \\
$\mathbf{6}$ & $767 \pm 35$ & $43.2 \pm 2.6$ & $678 \pm 44$ \\
$\mathbf{7}$ & $38.9 \pm 3.2$ & $147 \pm 23$ & $565 \pm 37$ \\
$\mathbf{8}$ & $50.3 \pm 3.7$ & $168 \pm 34$ & $478 \pm 41$ \\
aspirin & $10.3 \pm 1.8$ & $5.33 \pm 0.45$ & $545 \pm 36$ \\
ginkgolide B & $0.925 \pm 0.097$ & $75.6 \pm 1.0$ & $>999$ \\
\hline
\end{tabular}

${ }^{a}$ The data were expressed as means $95 \%$ confidence intervals of 4 rabbits.

\section{RESULTS AND DISCUSSION}

The in vitro abilities of the compounds $\mathbf{1 - 8}$ to inhibit the isozymes COX-1 and COX-2 (which appeared to be dose-dependent) were determined in the COX-catalyzed transformation of AA into $\mathrm{PGH}_{2}$, which was then reduced to $\mathrm{PGF}_{2 \alpha}$ and detected by the enzyme immunoassay (EIA), following the reported methodology (Rao et al. 2003), whose results are shown in Table I. Whereas lignans $\mathbf{1}, \mathbf{4}$ and 7-8 showed an activity against COX-2 ( $\mathrm{IC}_{50}$ 7.21-49.6 $\mu \mathrm{M}$ range), the dihydrochalcone 6 displayed a very low activity. However, 6 was the most potent COX-1 inhibitor ( $\left.\mathrm{IC}_{50} 1.22 \mu \mathrm{M}\right)$ among test compounds, being three times less active than the control. Aryltetralin (1-3) and dibenzylbutane (7-8) lignans exhibited selective inhibition against COX-2, and the dibenzylbutane lignans were significantly more active than the aryltetralins, and threo-isomer 8 was a better inhibitor than the meso-isomer 7. The furofuran lignans (3-5) inhibited the action of both COX isozymes with lower selectivity, although 4 was almost fifteen times more selective than $\mathbf{5}$.

The in vitro inhibitory effect of compounds 1-8 against 5-LOX was determined in the lipoxygenation reaction using a purified lipoxygenase to transform AA into hydroperoxides, which are detected and measured by the addition of a chromogen, following the reported methodology (Chowdhury et al. 2008). As expected, compounds having a free phenolic $\mathrm{OH}$ group $(\mathbf{1 - 2}, \mathbf{4 -}$
5) inhibited 5-LOX ( $\mathrm{IC}_{50} 4.22-18.2 \mu \mathrm{M}$ range), 5 being the most potent 5-LOX inhibitor that had a comparable activity $\left(\mathrm{IC}_{50} 4.22 \mu \mathrm{M}\right)$ to that of the positive control that was used (caffeic acid, $\mathrm{IC}_{50} 3.73 \mu \mathrm{M}$ ). Compounds 3 and 6-8 exhibited weak 5-LOX inhibitory effect ( $\mathrm{IC}_{50}$ 46.4 to $127 \mu \mathrm{M})$. Regarding the diastereomeric lignans 7-8, the meso-isomer $\mathbf{7}$ was displayed a lower $\mathrm{IC}_{50}$ value than its threo-isomer $\mathbf{8}$, in contrast to their COX-inhibition. By comparing the COX and 5-LOX inhibition results, 4 appeared to be the best candidate as a COX-2/5LOX dual inhibitor, which is a current matter of interest in the development of anti-inflammatory agents (Chowdhury et al. 2008, Charlier and Michaux 2003).

In addition, the capability to inhibit the aggregation of rabbit platelets induced by PAF, AA and ADP was evaluated in vitro, according to the reported method (Koch 2005), whose results are shown in Table II. Compounds 1-3 showed no significant antiplatelet effect in the test. Compound 6 had the highest $\mathrm{IC}_{50}$ value for AA-induced platelet aggregation, indicating that the antiplatelet activity is likely a consequence of COX-1 inhibition. Lignans 4-5 were found to be the most active compounds, since they inhibited the platelet aggregation induced by the three agonists, showing important selectivity for PAF-induced aggregation. The diastereomeric dibenzylbutane lignans 7-8 also displayed selectivity towards PAF-inhibition, the threo-isomer being more active than the meso-isomer. All compounds showed lower activity than the positive controls; how- 
ever, compound $\mathbf{5}$ presented a valuable pharmacological profile, because of its COX-2/5-LOX dual inhibition and antiplatelet activities. Recently, a very closely related compound isolated from Magnolia fargesii (Magnoliaceae) was found to be a good inhibitor of the production of nitric oxide (NO) and $\mathrm{PGE}_{2}$, as well as the expression of inducible nitric oxide synthase (iNOS) and COX-2, respectively, through the suppression of $\mathrm{I} \kappa \mathrm{B} \alpha$ degradation and $\mathrm{NF} \kappa \mathrm{B}$ activation (Kim et al. 2009).

In conclusion, these results imply that aryltetralin and furofuran lignans might be excellent candidates for further studies aiming for structural optimization to improve their activity, and delineate their anti-inflammatory effects. Our study clearly demonstrated that these lignans have good anti-inflammatory properties that are in agreement with the literature (Lin et al. 2007, da Silva Filho et al. 2004, Ballabeni et al. 2007, Kim et al. 2009, Kim and Yun-Choi 2007, Chen et al. 1996, Morais et al. 1999, Jesus-Morais et al. 2000). However, further structure-activity studies and biological analyses are required to clarify the underlying mechanism and to draw unambiguous conclusions regarding the antiinflammatory potential of aryltetralin and furofuran lignans.

\section{List of ABBREVIATIONS}

\begin{tabular}{|c|c|}
\hline${ }^{13} \mathrm{C}$ NMR & carbon nuclear magnetic resonance \\
\hline${ }^{1} \mathrm{H}$ NMR & hydrogen nuclear magnetic resonance \\
\hline 2D NMR & $\begin{array}{l}\text { two-dimensional nuclear magnetic } \\
\text { resonance }\end{array}$ \\
\hline AA & arachidonic acid \\
\hline ADP & adenosine diphosphate \\
\hline $\mathrm{CC}$ & column chromatography \\
\hline $\mathrm{CDCl}_{3}$ & deuterated chloroform \\
\hline $\mathrm{CHCl}_{3}$ & chloroform \\
\hline $\mathrm{COX}$ & cyclooxigenase \\
\hline DMSO & dimethyl sulfoxide \\
\hline EIA & enzyme immunoassay \\
\hline ESI & electrospray ionization \\
\hline $\mathrm{Et}_{2} \mathrm{O}$ & diethyl ether \\
\hline EtOAc & ethyl acetate \\
\hline HRMS & high resolution mass spectrometry \\
\hline $\mathrm{IC}_{50}$ & $\begin{array}{l}\text { half-maximal inhibition concentrations } \\
\text { (in } \mu \mathrm{M} \text { ) }\end{array}$ \\
\hline iNOS & inducible nitric oxide synthase \\
\hline LOX & lipoxygenase \\
\hline
\end{tabular}

$\begin{array}{ll}\text { LTs } & \text { leukotrienes } \\ m / z & \text { mass/charge relationship } \\ \text { MeCN } & \text { acetonitrile } \\ \text { MeOH } & \text { methanol } \\ \text { NSAIDs } & \text { nonsteroidal anti-inflammatory drugs } \\ & \text { (NSAIDs) } \\ \text { PAF } & \text { platelet activating factor } \\ \text { PGHS } & \text { prostaglandin } \mathrm{H}_{2} \text { synthase } \\ \text { PGs } & \text { prostaglandins } \\ \text { PRP } & \text { platelet-rich plasma } \\ \text { qToF } & \text { quadrupole time of flight } \\ \text { TMS } & \text { tetramethylsilane } \\ \text { TxA } 2 & \text { thromboxane } \\ \text { UV } & \text { ultraviolet }\end{array}$

\section{ACKNOWLEDGMENTS}

We thank the Division de Investigación Sede Bogotá (DIB) (Call 2009, Project Code No 8003383), and the Chemistry Department, Universidad Nacional de Colombia, for the financial support.

\section{RESUMO}

Os efeitos anti-inflamatórios in vitro de sete conhecidos lignanos e uma dihidrocalcona isolados das folhas de duas espécies da família Lauraceae (Pleurothyrium cinereum e Ocotea macrophylla) foram avaliados por meio da inibição da COX1, COX-2, 5-LOX e agregação de plaquetas de coelhos induzida por PAF, AA e ADP. A (+)-4" $-O$-metilmagnolina-4 foi encontrada como mais potente inibidora tanto da COX-2 quanto de 5-LOX e antagonista de PAF (COX-2 IC $_{50} 2,27 \mu \mathrm{M}$; 5LOX IC $_{50} 5,05 \mu \mathrm{M}$; PAF $\left.\mathrm{IC}_{50} 2,51 \mu \mathrm{M}\right)$. Entretanto, todos compostos mostram uma atividade em intensidades diferentes, indicando boas propriedades anti-inflamátorias a serem consideradas para futuros estudos de modificações e otimização estruturais.

Palavras-chave: COX, lignanos furofurânicos, 5-LOX, Ocotea macrophylla, agregação plaquetária, Pleurothyrium cinereum.

\section{REFERENCES}

ARMSTRONG RA. 1996. Platelet prostanoid receptors. Pharmacol Ther 72: 171-191.

Ballabeni V, Tognolini M, Bertoni S, Bruni R, Guerrini A, Moreno-Rueda GA ND BARocelli 
E. 2007. Antiplatelet and antithrombotic activities of essential oil from wild Ocotea quixos (Lam.) Kosterm. (Lauraceae) calices from Amazonian Ecuador. Pharmacol Res 55: 23-30.

Bombardier C ET AL. 2000. Comparison of upper gastrointestinal toxicity of rofecoxib and naproxen in patients with rheumatoid arthritis. N Engl J Med 343: 1520-1528.

Charlier C and Michaux C. 2003. Dual inhibition of cyclooxygenase-2 (COX-2) and 5-lipoxygenase (5-LOX) as a new strategy to provide safer non-steroidal anti-inflammatory drugs. Eur J Med Chem 38: 645-659.

Chen CC, Hsin WC, Ko FN, HuAng YL, OU JC AND TENG CM. 1996. Antiplatelet arylnaphthalide lignans from Justicia procumbens. J Nat Prod 59: 1149-1150.

Chowdhury MA, Abdellatif KRA, Dong Y, Das D, SURESH MR AND KNAUS EE. 2008. Synthesis of celecoxib analogs that possess a $N$-hydroxypyrid-2(1H)one 5-lipoxygenase pharmacophore: Biological evaluation as dual inhibitors of cyclooxygenases and 5-lipoxygenase with anti-inflammatory activity. Bioorg Med Chem Lett 18: 6138-6141.

CoY ED AND CUCA LE. 2008a. Chemical constituents from Pleurothyrium cinereum (van der Werff) (Lauraceae) from Colombia. Biochem System Ecol 36: 674-677.

Coy ED AND CuCA LE. 2008b. Nuevo alcaloide oxoaporfínico y otros constituyentes químicos aislados de Pleurothyrium cinereum (lauraceae). Rev Colomb Quim 37: 127-134.

Coy ED, CuCA LE And SEFKOW M. 2010. Pd-NHC catalyzed biaryl coupling by direct $\mathrm{C}-\mathrm{H}$ activation - a novel strategy for the synthesis of dibenzocyclooctane lignans. Synth Comm 40: 41-51.

Da Silva Filho AA, Andrade E Silva ML, Carvalho JCT AND BASTOS JK. 2004. Evaluation of analgesic and anti-inflammatory activities of Nectandra megapotamica (Lauraceae) in mice and rats. J Pharm Pharmacol 56: 1179-1184.

Jesus-Morais CM, Assis EF, CORdeiro RS, BARBosaFilho JM, Lima WT, Silva ZL, Bozza PT AND CAstro-FARIA-Neto HC. 2000. Yangambin, a lignan obtained from Ocotea duckei, differentiates putative PAF receptor subtypes in the gastrointestinal tract of rats. Planta Med 66: 211-216.
Kim JY, LiM HJ, LEE DY, Kim JS, Kim DH, LEE HJ, KIM HD, JEON R AND RYU JH. 2009. In vitro antiinflammatory activity of lignans isolated from Magnolia fargesii. Bioorg Med Chem Lett 19: 937-940.

KIM SY AND YUN-CHOI HS. 2007. Platelet anti-aggregating activities of bupleurumin from the aerial parts of Bupleurum falcatum. Arch Pharm Res 30: 561-564.

KOCH E. 2005. Inhibition of platelet activating factor (PAF)induced aggregation of human thrombocytes by ginkgolides: considerations on possible bleeding complications after oral intake of Ginkgo biloba extracts. Phytomedicine 12: $10-16$.

Konstam MA, Weir Mr, Reicin A, Shapiro D, SperLING RS, BARR E AND GERTZ BJ. 2001. Cardiovascular thrombotic events in controlled, clinical trials of rofecoxib. Circulation 104: 2280-2288.

Lin CT, Chu FH, Tseng YH, Tsai JB, Chang ST AND WANG SY. 2007. Bioactivity investigation of Lauraceae trees grown in Taiwan. Pharmaceut Biol 45: 638-644.

Morais LCSL, Almeida RN, DA-Cunha EVL, DA-SilVA MS, BARbosa-Filho JM AND GRAY AI. 1999. Further lignans from Ocotea duckei. Pharmaceut Biol 37: 144-147.

Prescott SM, McIntyre TM, Zimmerman GA AND STAFFORINI DM. 2002. Sol Sherry Lecture in Thrombosis: Molecular Events in Acute Inflammation. Arterioscler Thromb Vasc Biol 22: 727-733.

RAO GH. 1993. Physiology of blood platelet activation. Indian J Physiol Pharmacol 37: 263-275.

Rao PNP, Amini M, Li H, Habeeb aG and Knaus EE. 2003. Design, synthesis, and biological evaluation of 6-substituted-3-(4-methanesulfonylphenyl)-4-phenylpyran-2-ones: a novel class of diarylheterocyclic selective cyclooxygenase-2 inhibitors. J Med Chem 46: 4872 4882.

Simmons DL, Botting RM and Hla T. 2004. Cyclooxygenase isozymes: the biology of prostaglandin synthesis and inhibition. Pharmacol Rev 56: 387-437.

TIBIRIÇÁ E. 2001. Cardiovascular properties of yangambin, a lignan isolated from Brazilian plants. Cardiovasc Drug Rev 19: 313-328. 